\title{
Dampak Pertambangan Batubara terhadap Laju Deforestasi di Kabupaten Kutai Kartanegara Provinsi Kalimantan Timur
}

\section{The Impact of Coal Mining on Deforestation Rates in Kutai Kartanegara Regency of East Kalimantan Province}

\author{
Retna Kartikasari ${ }^{1 *}$, Arief Rachmansyah², Amin Setyo Leksono ${ }^{3}$ \\ ${ }^{1}$ Pengelolaan Sumberdaya Lingkungan dan Pembangunan, Program Pascasarjana, Universitas Brawijaya \\ 2Jurusan Teknik Sipil, Fakultas Teknik, Universitas Brawijaya \\ 3Jurusan Biologi, Fakultas Matematika dan Ilmu Pengetahuan Alam, Universitas Brawijaya
}

\begin{abstract}
Abstrak
Pertambangan batubara di Kalimantan Timur merupakan salah satu kegiatan yang menyebabkan perubahan penutupan lahan hutan menjadi non hutan. Perubahan penutupan lahan tersebut mengakibatkan terjadinya deforestasi baik didalam kawasan hutan maupun diluar kawasan hutan. Artikel ini akan membahas laju deforestasi berdasarkan perubahan tutupan lahan pada areal pertambangan batubara yang berada di kawasan hutan di Kabupaten Kutai Kartanegara. Penelitian dilakukan dengan menginterpretasikan pola penutupan lahan pada citra Landsat 5 TM dan Landsat 7 ETM+ tahun 2010 serta Landsat 8 OLI/TIRS tahun 2016. Hasil analisis berupa perubahan tutupan lahan tahun 2010 dan tahun 2016. Berdasarkan perubahan tutupan lahan tersebut, dilakukan pencermatan pada areal hutan yang berubah menjadi areal non hutan sehingga didapatkan laju deforestasi. Hasil penelitian menunujukkan, bahwa pada kurun waktu antara tahun 2010 sampai dengan tahun 2016, laju deforestasi yang terjadi pada areal pertambangan batubara dalam kawasan hutan sebesar $223,83 \mathrm{Ha}$ /tahun. Luas laju deforestasi tersebut $\pm 0,46 \%$ dari luas total izin pertambangan batubara dalam kawasan hutan yang berarti bahwa kontribusi kegiatan pertambangan batubara pada deforestasi didalam kawasan hutan sangat kecil.
\end{abstract}

Kata kunci: pertambangan batubara, kawasan hutan, citra landsat, perubahan tutupan lahan, laju deforestasi

\section{Abstract}

Coal mining in East Kalimantan is one of the activities that causes the land cover change from forest to non forest. It results in deforestation both in the forest area and outside forest area. This article will discuss the rate of deforestation based on changes in land cover by coal mining area located in forest area in Kutai Kartanegara Regency. The study was conducted by analyzing 2010 Landsat 5 TM and Landsat 7 ETM + and 2016Landsat 8 OLI / TIRS. The result of the analysis is land cover change year 2010 and year 2016. Based on the land cover change in $2010-2016$, the deforestation rate is observed in forest area in which change to non forest land cover. The study shows that, between 2010 to 2016, the rate of deforestation occurring in the coal mining area within the forest area is $223.83 \mathrm{Ha} /$ year. The deforestation rate is about $0.46 \%$ of the total area of coal mining permits within the forest area. It means that the contribution of coal mining to deforestation in the forest area is very small.

Keywords: coal mining, forest area, land cover change, deforestation rate

\section{PENDAHULUAN}

Pertambangan batubara merupakan salah satu kegiatan yang dapat mendorong pertumbuhan perekonomian Indonesia selama satu dasawarsa terakhir. Di sisi lain, kehutanan juga merupakan salah satu sektor pendukung perekonomian sekaligus memberikan jasa ekosistem yang sangat beragam, mulai dari oksigen, air, dan keanekaragaman hayati. Sektor

\footnotetext{
Correspondence address:

Retna Kartikasari

Email : retna4k@gmail.com

Address : Program Pascasarjana, Universitas Brawijaya J. MT. Haryono 169 Malang 651145
}

kehutanan telah menyumbang produk domestik bruto sebesar 8,13\% pada tahun 2015, sementara pada tahun yang sama komoditi batubara memberikan kontribusi sebesar $8,53 \%$ [1].

Seluas 6,028,414 $\mathrm{Ha}$ izin pertambangan di Kalimantan berada didalam kawasan hutan [2]. Di wilayah Kabupaten Kutai Kartanegara Provinsi Kalimantan Timur sebagian besar kegiatan pertambangan batubara berlangsung didalam kawasan hutan. Kegiatan ini diwadahi dalam kegiatan pengelolaan hutan yaitu penggunaan kawasan hutan melalui mekanisme izin pinjam pakai kawasan hutan sebagai upaya untuk mengatasi tumpang tindih antara sektor 
kehutanan dengan sektor pembangunan lainnya yang berbasis lahan.

Pada umumnya kegiatan pertambangan batubara dilakukan dengan sistem pertambangan terbuka karena seam batubara terletak di dekat permukaan. Dengan menggunakan sistem pertambangan terbuka, secara langsung akan mempengaruhi perubahan penutupan lahan dari areal hutan menjadi areal bukan hutan atau dikenal dengan deforestasi. Deforestasi juga didefinisikan sebagai areal berhutan berubah akibat aktivitas manusia dan/atau gangguan alam [3].

Studi mengenai deforestasi memerlukan sejarah penggunaan dan penutupan lahan yang dapat dideteksi dengan menggunakan teknologi penginderaan jauh satelit. Pemantuan hilangnya tutupan hutan pada hutan tropis basah yang memiliki tingkat kehilangan bervariasi dapat menggunakan data penginderaan jauh multi resolusi [4]. Studi tentang penilaian dampak lingkungan dan perubahan penutupan dan penggunaan lahan pada areal pertambangan batubara dapat menggunakan data citra satelit [5].

Studi Abood et al. (2015) menunjukkan, antara tahun 2000 - 2010 di Indonesia telah terjadi kehilangan tutupan hutan sebesar $44.7 \%$ pada areal konsesi hak pengusahaan hutan alam, hutan tanaman industri, perkebunan kelapa sawit, dan pertambangan [6]. Menindaklanjuti studi tersebut, maka diperlukan areal konsesi yang lebih khusus, yaitu izin pinjam pakai kawasan hutan untuk pertambangan batubara. Tujuan dari studi ini adalah untuk menganalisis perubahan penutupan lahannya dan seberapa besar deforestasi yang terjadi di kawasan ini.

\section{METODE PENELITIAN}

Data yang digunakan adalah citra Landsat 5 TM dan Landsat 7 ETM+ tahun 2010 serta Landsat 8 OLI/TIRS tahun 2016 dan peta sebaran izin pinjam pakai kawasan hutan di Kabupaten Kutai Kartanegara.

Citra satelit Landsat 5 TM, 7 ETM+, dan 8 OLI/TIRS pada path/row 117/060, 116/060, dan $116 / 061$. Ketiga scene pada path/row tersebut merupakan scene yang meliputi sebaran areal izin pinjam pakai kawasan hutan untuk pertambangan batubara di Kabupaten Kutai Kartanegara. Citra Landsat diunduh dari situs www.earthexplorer.usgs.gov dengan waktu perekaman antara Januari - Desember 2010 untuk Landsat 5 TM dan dan ETM+ serta Januari - Desember 2016 untuk Landsat 8 OLI/TIRS.
Diantara rentang waktu tersebut, dipilih scene citra yang tingkat keawanan pada areal izin pinjam pakai kawasan hutan rendah atau sedikit.

Dari hasil unduhan citra tersebut, dilakukan pra-pengolahan citra seperti koreksi geometri, gapfill (Frame \& Fill Win 3.2), pemotongan dan penggabungan scene sesuai dengan kebutuhan untuk tahap interpretasi citra. Interpretasi citra Landsat 5 TM dan 7 ETM+ menggunakan komposit band 543 dan citra Landsat 8 OLI/TIRS menggunakan komposit band 654. Komposit band yang digunakan merupakan komposit warna false natural color yang dipandang dapat membedakan warna vegetasi, non vegetasi, dan tanah secara lebih jelas. Penggunaan komposit warna tersebut berdasarkan SNI 7645:2010 tentang Klasifikasi Penutup Lahan [7] dan Peraturan Direktur Jenderal Planologi Kehutanan Nomor P.1/VII-IPSDH/2015 tentang Pedoman Pemantauan Sumber Daya Hutan [8].

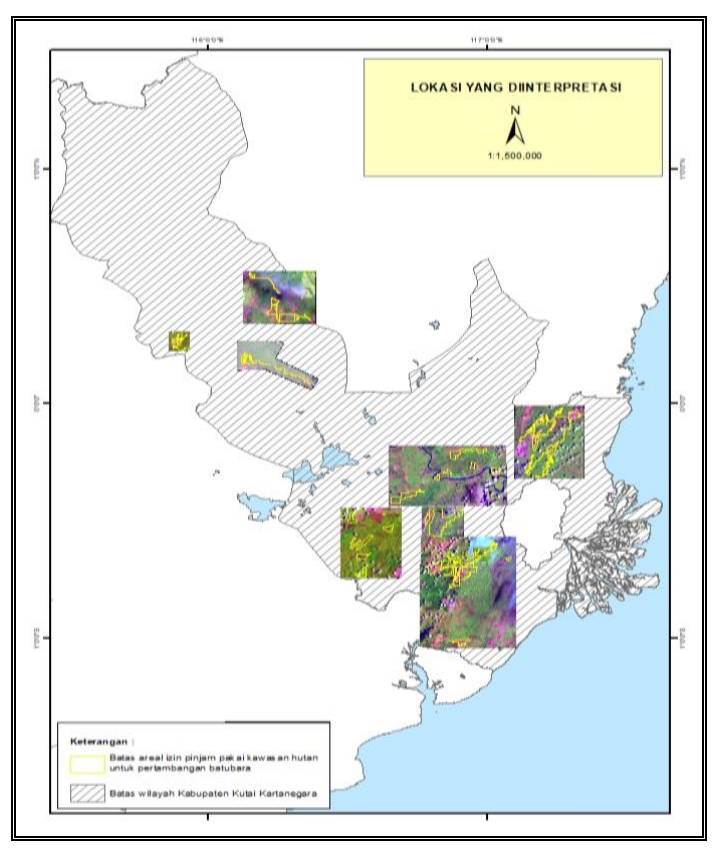

Gambar 1. Lokasi yang Diinterpretasi Penutupan Lahannya

Data sebaran izin pinjam pakai kawasan hutan untuk pertambangan batubara di Kabupaten Kutai Kartanegara berupa data vector (*.shp) diperoleh dari Ditjen Planologi dan Tata Lingkungan, Kementerian Lingkungan Hidup dan Kehutanan. Data ini menjadi dasar atau batas areal yang akan diinterpretasi.

Area contoh terpilih diambil dari Google Earth menggunakan software QGIS 2.18. Berdasarkan area terpilih, dilakukan klasifikasi terbimbing (supervised classification) menggunakan metode 
kemungkinan maksimum (maximum likelihood) dengan software Erdas Imagine 2014, sehingga didapatkan peta penutupan lahan pada areal izin pinjam pakai kawasan hutan untuk pertambangan batubara tahun 2010 dan tahun 2016. Hasil klasifikasi ini dijadikan dasar untuk analisis perubahan lahan menggunakan postclassification comparison change detection [9].

Peta penutupan lahan pada 2 waktu tersebut kemudian dianalisis perubahan tutupan lahannya menggunakan software ArcGIS 10.0. Hasil akhir pengolahan data berupa luasan tutupan lahan dihitung menggunakan Microsoft Office Excel.

Hasil analisis perubahan lahan pada penelitian ini dipakai untuk menentukan deforestasi yang dirumuskan dengan persamaan sebagai berikut.

$$
P_{T H}=A_{1}-A_{0}
$$

$\mathrm{P}_{\mathrm{TH}}$ adalah luas perubahan tutupan hutan pada periode tertentu $(\mathrm{Ha})$,

$A_{0}$ adalah luas hutan pada waktu pengamatan awal ( $\mathrm{Ha})$, dan

$A_{1}$ adalah luas hutan pada waktu pengamatan akhir (Ha).

$\mathrm{P}_{\mathrm{TH}}$ bernilai positif, maka terjadi penambahan tutupan hutan (reforestasi). PTH yang bernilai negatif, berarti terjadi pengurangan tutupan hutan (deforestasi).

Persamaan tersebut dimodifikasi dari rumus perubahan tutupan lahan sesuai SNI 8033:2014 tentang Metode Penghitungan Perubahan Tutupan Hutan Berdasarkan Hasil Penafsiran Citra Penginderaan Jauh Optik Secara Visual [10].

$$
N_{\text {Def }}=\text { Def }- \text { Ref }
$$

NDef adalah deforestasi Bersih ( $\mathrm{Ha}$ ), Def adalah deforestasi bruto $(\mathrm{Ha})$, dan Ref adalah reforestasi (Ha)

Untuk mendapatkan besarnya nilai laju deforestasi, persamaan yang digunakan adalah sebagai berikut.

$$
L_{\text {def }}=\frac{N_{\text {def }}}{T_{1}-T_{0}}
$$

$L_{\text {def }}$ adalah laju deforestasi pada periode waktu tertentu ( $\mathrm{Ha} /$ tahun).

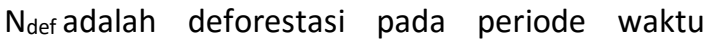
tertentu ( $\mathrm{Ha}$ ).

To adalah waktu pengamatan awal $(\mathrm{Ha})$

$\mathrm{T}_{1}$ adalah waktu pengamatan akhir $(\mathrm{Ha})$

\section{HASIL DAN PEMBAHASAN}

Kabupaten Kutai Kartanegara adalah salah satu kabupaten di wilayah Provinsi Kalimantan Timur dengan potensi sumberdaya alam non hayati berupa batubara yang cukup besar. Batubara menjadi sumber pendapatan daerah selain migas. Selain itu, sumber daya hutan yang ada di kabupaten ini juga sangat besar yaitu 2.435.513,61 $\mathrm{Ha}$ atau 89,33\% dari luas total wilayah ini. Dari luas hutan tersebut, sekitar 898.280,30 Ha merupakan kawasan hutan.

Berdasarkan data sebaran izin pinjam pakai kawasan hutan untuk pertambangan batubara sampai tahun 2016, terdapat 38 unit izin seluas 48,037.79 Ha. Izin ini tersebar di seluruh wilayah Kabupaten Kutai Kartanegara, terutama di wilayah timur. Izin tersebut berada pada kawasan hutan:

1. Hutan Produksi Terbatas (HPT) seluas 2.276,22 $\mathrm{Ha}$

2. Hutan Produksi Tetap (HP) seluas $31.244,70$ $\mathrm{Ha}$

3. Hutan Produksi yang dapat Dikonversi (HPK) seluas $30,82 \mathrm{Ha}$

4. Areal Penggunaan Lain (APL) seluas $14.479,66$ $\mathrm{Ha}$

5. Tubuh air seluas $6,39 \mathrm{Ha}$

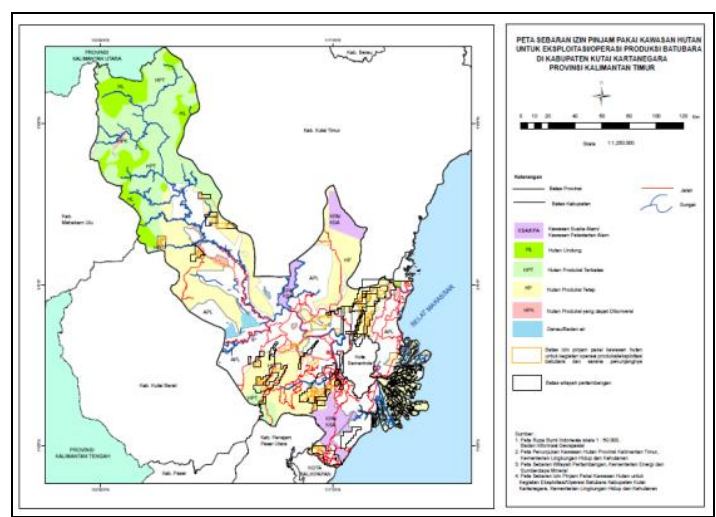

Gambar 1 Peta Sebaran Izin Pinjam Pakai Kawasan Hutan untuk Pertambangan Batubara di Kabupaten Kutai Kartanegara Provinsi Kalimantan Timur sampai Tahun 2016

Hasil interpretasi citra Landsat tahun 2010 dan tahun 2016 pada areal izin pinjam pakai kawasan hutan menunjukkan adanya penutupan lahan berupa areal hutan dan areal bukan hutan. Hutan lahan kering sekunder dan hutan tanaman merupakan penutupan lahan yang dikategorikan sebagai areal berhutan. Luas izin yang berada di hutan lahan kering sekunder adalah $522,80 \mathrm{Ha}$ di tahun 2010 dan berkurang menjadi 517,57 Ha di tahun 2016. Izin yang berada didalam area hutan 
tanaman seluas 7.112,78 Ha di tahun 2010 dan berkurang di tahun 2016 menjadi 5.551,16 Ha.

Sementara itu, untuk kategori areal tidak berhutan terdiri dari semak, perkebunan, pertanian, tanah terbuka, pertambangan, permukiman, badan air, dan rawa. Semak belukar merupakan penutupan lahan yang mendominasi area izin pertambangan didalam kawasan hutan. Pada tahun 2010, luas semak belukar adalah 31.741,82 Ha dan berturut-turut sampai luas terkecil adalah pertambangan $(3.906,26 \mathrm{Ha})$, tanah terbuka $(3.252,95 \mathrm{Ha})$, badan air $(639,53 \mathrm{Ha})$, sawah $(321,11 \mathrm{Ha})$, pertanian lahan kering campur semak $(283,22$ $\mathrm{Ha})$, semak belukar rawa $(205,46 \mathrm{Ha})$, pertanian lahan kering $(22,31 \mathrm{Ha})$, perkebunan $(20,87 \mathrm{Ha})$, permukiman $(8,27 \mathrm{ha})$, dan rawa $(0,36 \mathrm{Ha})$.

Di tahun 2016, luas areal bukan hutan, adalah semak belukar $(28.416,03 \mathrm{Ha})$, tanah terbuka $(6.069,87 \mathrm{Ha})$, pertambangan $(5.262,91 \mathrm{Ha})$, badan air $(1.115,92 \mathrm{Ha})$, pertanian lahan kering campur semak $(739,77 \mathrm{Ha})$, semak belukar rawa $(208,10 \mathrm{Ha})$, sawah $(63,82 \mathrm{Ha})$, pertanian lahan kering $(23,91 \mathrm{Ha})$, permukiman $(22,70 \mathrm{Ha})$ dan rawa $(0,36 \mathrm{Ha})$

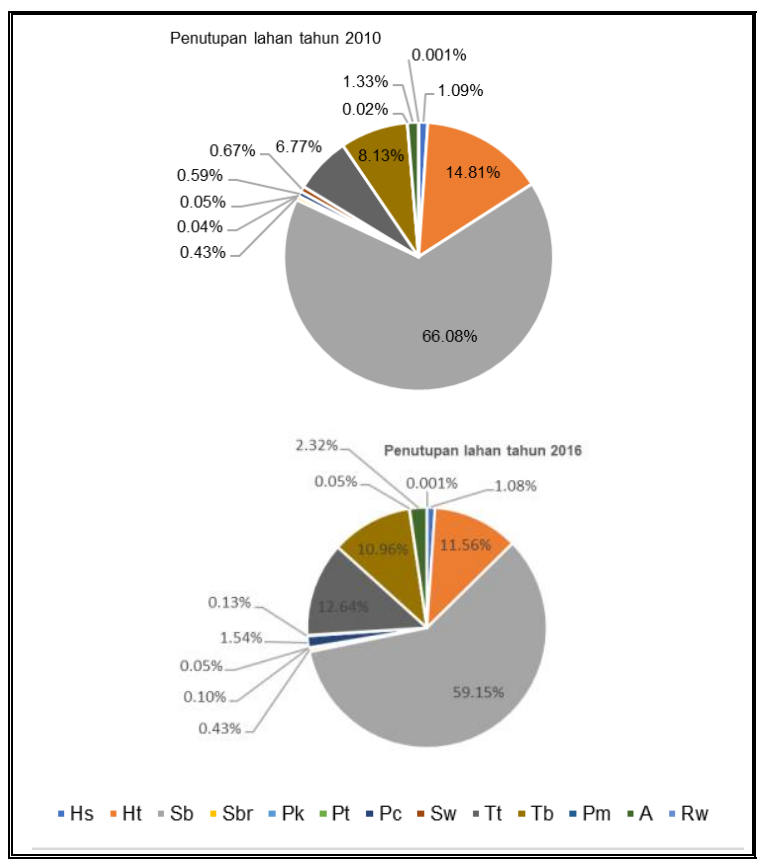

Gambar 2 Grafik Persentase Luas Penutupan Lahan pada Areal Izin Pinjam Pakai Kawasan Hutan untuk Pertambangan Batubara Tahun 2010 dan Tahun 2016

Luas penutupan lahan tesebut mengalami perubahan, baik peningkatan maupun pengurangan. Umumnya, areal bukan hutan meningkat luasannya dalam kurun waktu 7 tahun (2010 - 2016). Areal pertambangan menjadi areal yang peningkatan cukup tinggi dan semak belukar mengalami pengurangan yang cukup luas.

Untuk kelas areal hutan, penutupan lahan pada areal izin pinjam pakai kawasan hutan berupa hutan lahan kering sekunder dan hutan tanaman masing-masing berkurang $0.01 \%$ dan $3.25 \%$ pada tahun 2016. Kelas areal bukan hutan, yaitu semak belukar dan sawah mengalami penurunan luasan di tahun 2016. Sekitar 6.92\% luas semak belukar telah berubah menjadi tanah terbuka dan areal pertambangan, semak belukar rawa, perkebunan, pertanian lahan kering, pertanian lahan kering campur semak, permukiman dan badan air. Selanjutnya, luas sawah berkurang $0.54 \%$ menjadi semak belukar, areal pertambangan, pertanian lahan kering campur semak, tanah terbuka, dan badan air.

Areal bukan hutan lainnya mengalami peningkatan luas seperti pertambangan yang mengalami peningkatan $2.82 \%$ di tahun 2016 . Tanah terbuka juga meningkat luasannya sebesar $5.86 \%$. Perubahan penutupan lahan yang menjadi badan air mengalami peningkatan hampir 50\%, dari seluas 639,53 ha di tahun 2010 menjadi 1.115,92 ha di tahun 2016.

Dari analisis perubahan lahan, dicermati perubahan dari kelas areal hutan yang mengalami perubahan menjadi kelas bukan hutan untuk mendapatkan besaran deforestasi pada areal izin pinjam pakai kawasan hutan.

Tabel 1 Luas Deforestasi pada Areal Izin Pinjam Pakai Kawasan Hutan untuk Pertambangan Batubara di Kabupaten Kutai Kartanegara Provinsi Kalimantan Timur Tahun 2010 - 2016

\begin{tabular}{|c|c|c|c|}
\hline \multirow{2}{*}{ No } & \multicolumn{2}{|c|}{ Penutupan Lahan } & \multirow{2}{*}{$\begin{array}{l}\text { Luas } \\
(\mathrm{Ha})\end{array}$} \\
\hline & Tahun 2010 & Tahun 2016 & \\
\hline 1 & $\begin{array}{l}\text { Hutan lahan } \\
\text { kering sekunder }\end{array}$ & Semak belukar & 7.99 \\
\hline 2 & $\begin{array}{l}\text { Hutan lahan } \\
\text { kering sekunder }\end{array}$ & Tanah terbuka & 14.83 \\
\hline 3 & Hutan tanaman & Semak belukar & 501.01 \\
\hline 4 & Hutan tanaman & Perkebunan & 0.45 \\
\hline 5 & Hutan tanaman & $\begin{array}{l}\text { Pertanian lahan } \\
\text { kering campur } \\
\text { semak }\end{array}$ & 1.35 \\
\hline 6 & Hutan tanaman & Tanah terbuka & 844.90 \\
\hline 7 & Hutan tanaman & Pertambangan & 925.18 \\
\hline 8 & Hutan tanaman & Badan air & 258.73 \\
\hline & & Jumlah & $2.554,44$ \\
\hline
\end{tabular}

Sumber: Pengolahan data

Areal berhutan yang mengalami perubahan menjadi areal tidak berhutan adalah hutan lahan 
kering sekunder dan hutan tanaman. Hutan lahan kering sekunder berubah menjadi semak belukar dan tanah terbuka. Hutan tanaman berubah menjadi semak belukar, perkebunan, pertanian lahan kering campur semak, tanah terbuka dan pertambangan serta badan air. Perubahan tutupan lahan tersebut dihitung sebagai hilangnya tutupan areal berhutan atau dikatakan sebagai deforestasi. Deforestasi terbesar terjadi pada hutan tanaman yang digunakan untuk kegiatan pertambangan batubara, yaitu seluas $925.18 \mathrm{Ha}$ atau $1.92 \%$ dari luas areal pinjam pakai kawasan hutan di wilayah Kabupaten Kutai Kartanegara.

Tabel 2 Luas Reforestasi pada Areal Izin Pinjam Pakai Kawasan Hutan untuk Pertambangan Batubara di Kabupaten Kutai Kartanegara Provinsi Kalimantan Timur Tahun 2010 - 2016

\begin{tabular}{|c|c|c|c|}
\hline \multirow{2}{*}{ No } & \multicolumn{2}{|c|}{ Penutupan Lahan } & \multirow{2}{*}{$\begin{array}{l}\text { Luas } \\
\text { (Ha) }\end{array}$} \\
\hline & Tahun 2010 & Tahun 2016 & \\
\hline 1 & Semak belukar & $\begin{array}{l}\text { Hutan lahan } \\
\text { kering sekunder }\end{array}$ & 0,36 \\
\hline 2 & Semak belukar & Hutan tanaman & 171,48 \\
\hline 3 & $\begin{array}{l}\text { Pertanian lahan } \\
\text { kering campur } \\
\text { semak }\end{array}$ & Hutan tanaman & 6,55 \\
\hline 4 & Tanah terbuka & $\begin{array}{l}\text { Hutan lahan } \\
\text { kering sekunder }\end{array}$ & 4,33 \\
\hline 5 & Tanah terbuka & Hutan tanaman & 482,24 \\
\hline 6 & Pertambangan & Hutan tanaman & 259,63 \\
\hline \multirow[t]{2}{*}{7} & Badan air & Hutan tanaman & 53,02 \\
\hline & & Jumlah & 987,61 \\
\hline
\end{tabular}

Pada areal pinjam pakai kawasan hutan untuk pertambangan batubara ini, terdapat perubahan penutupan areal tidak berhutan menjadi areal berhutan, seperti semak belukar menjadi hutan lahan kering sekunder dan hutan tanaman, pertanian lahan kering campur semak menjadi hutan tanaman, tanah terbuka menjadi hutan lahan kering sekunder dan hutan tanaman, pertambangan menjadi hutan tanaman, dan badan air menjadi hutan tanaman. Perubahan ini terjadi pada areal pertambangan batubara yang telah direklamasi dan direvegetasi sehingga areal yang semula terbuka atau bervegetasi selain pohon (semak belukar dan pertanian lahan kering campur semak) menjadi areal bervegetasi pepohonan. Dengan adanya penutupan lahan tidak berhutan menjadi berhutan akan mengurangi luas areal terdeforestasi atau dengan kata lain terdapat reforestasi.

Berdasarkan hasil perhitungan, deforestasi di areal pinjam pakai kawasan hutan sebesar $2.554,44 \mathrm{Ha}(5,31 \%)$ dan reforestasi seluas $987,61 \mathrm{Ha}(2,05 \%)$. Dengan demikian, deforestasi bersih yang terjadi pada areal izin pinjam kawasan hutan antara tahun 2010 sampai dengan 2016 adalah 1.566,83 ha (3,26\%) atau laju deforestasi yang terjadi sebesar 223,83 ha/tahun. Luas laju deforestasi tersebut sangat kecil dibadingkan luas total izin pertambangan didalam kawasan hutan yang mencapai 48.037,79 Ha.

\section{KESIMPULAN}

Perubahan pola penutupan lahan pada areal izin pinjam pakai kawasan hutan untuk pertambangan batubara menunjukkan kecenderungan peningkatan luas untuk areal bukan hutan dan penurunan luas untuk areal hutan. Deforestasi bersih yang terjadi di areal izin ini sebesar $1.566,83$ ha atau $3,26 \%$ dari luas total areal izin pinjam pakai kawasan hutan untuk pertambangan batubara di Kabupaten Kutai Kartanegara. Selama kurun waktu 7 tahun (2010 - 2016), laju deforestasi yang terjadi sebesar 223,83 ha/tahun atau 0,46 \% dari luas areal izin pertambangan didalam kawasan hutan.

\section{UCAPAN TERIMA KASIH}

Penulis pertama ingin mengucapkan terima kasih kepada Dr. rer. Nat. Arief Rachmansyah dan Amin Setyo Leksono, S.Si, M.Si, Ph.D sebagai mentor yang membimbing dan mengarahkan penulis dalam melakukan penelitian ini. Juga, kepada Kementerian Lingkungan Hidup dan Kehutanan yang telah mendanai studi penulis melalui Program Karyasiswa.

\section{DAFTAR PUSTAKA}

[1].Badan Pusat Statistik. 2016. Sistem Terintergrasi Neraca LIngkungan dan Ekonomi Indonesia 2011 - 2015. Jakarta.

[2]. Koalisi Masyarakat Sipil Kalimantan. 2015. Hentikan Eksploitasi Sumber Daya Alam untuk Keselamatan Rakyat dan Keberlanjutan Lingkungan Hidup di Pulau Kalimantan. https://acch.kpk.go.id/images/ragam/gn-sda/ pontianak/02-Paparan-CSO-Kalimantan.pdf

[3]. Harris, Nancy L. dan Brown, Sandra dan Hagen, Stephen C. dan Saatchi, Sassan S. dan Petrova, Silvia dan Salas, William dan Hansen, Matthew C. dan Potapov, Peter V. dan Lotsch, Alexander. 2012. Baseline Map of Carbon 
Emissions from Deforestation in Tropical Regions. http://www.sciencemag.org.

[4]. Broich, Mark; Hansen, Matthew; Stolle, Fred; Potapov, Peter; Margono, Belinda Arunarwati; and Adusei, Bernard. 2011. Remotely sensed forest cover loss shows high spatial and temporal variation across Sumatera and Kalimantan, Indonesia 2000 2008. Environmental Research Letter. 6: 1 - 9.

[5].Samanta, Prasenjit. 2015. Impact Assessment and Changes Analysis of Land Use/ Land Cover Due to Open Cast Coal Mining Activity: A Case Study of Raniganj Coal Field Area. Dalam International Journal of IT, Engineering and Applied Sciences Research (IJIEASR), 4 (5): $17-26$.

[6].Abood, Sinan A. dan Lee, Janice Ser Huay dan Burivalova, Zuzana dan Ulloa, John Garcia dan Koh, Lian Pin. 2015. Relative Contributions of Logging, Fiber, Oil Palm, and Mining Industries to Forest Loss in Indonesia. Conservation Letters. 8 (1): 58 -67

[7]. Badan Standarisasi Nasional. 2010. SNI 7645:2010 Klasifikasi Penutup Lahan. Jakarta.

[8]. Direktorat Jenderal Planologi Kehutanan. 2015. Peraturan Direktur Jenderal Planologi Kehutanan Nomor P.1/VII-IPSDH/2015 tentang Pedoman Pemantauan Sumber Daya Hutan. http://webgis.menlhk.go.id:8080/pl/ pl.htm.

[9]. Badan Standarisasi Nasional, 2014. SNI 8033:2014 Metode Penghitungan Perubahan Tutupan Hutan Berdasarkan Hasil Penafsiran Citra Penginderaan Jauh Optik Secara Visual. Jakarta.

[10]. Jensen, J. R. 2005. Introductory Digital Image Processing - A Remote Sensing Perspective, 3rd Edition. New Jersey: Pearson Prentice Hall. 